\title{
THE STRUCTURE OF BASIC LEVEL CATEGORIES IN THE UKRAINIANS' CONSCIOUSNESS ACCORDING TO THE RESULTS OF PSYCHOLINGUISTIC EXPERIMENTS: PARKAN AND MUR ${ }^{1}$
}

\author{
Marharyta Zhuykova \\ mzhujkova@ukr.net \\ https://orcid.org/0000-0003-0396-8458 \\ Lesya Ukrainka Volyn \\ National University, Ukraine \\ Liliia Lavrynovych \\ lavrinovich.liliya@vnu.edu.ua \\ https://orcid.org/0000-0001-8588-9790 \\ Lesya Ukrainka Volyn \\ National University, Ukraine
}

Olha Svidzynska

triphilon@i.ua

https://orcid.org/0000-0003-3609-1752

State Historical and Cultural Reserve "Tustan", Ukraine

Received June 5, 2020; Revised September 4, 2020; Accepted September 27, 2020

\begin{abstract}
The aim of this research is to identify experimentally the structure (primarily the central zone) of two basic level categories in the Ukrainian speakers minds: PARKAN and MUR. To reach this goal 2 psycholinguistic experiments were designed and conducted. Within the first experiment the respondents were asked to determine whether the object on the picture belongs to the category PARKAN. Within the second one they were asked to determine whether the object on the picture belongs to the category MUR. For each experiment 75 images of the objects with similar functions and perceptual features were selected. The respondents had to choose integers 1-2-3 under the image, where 3 means that the object enters into the category, and 1 means that the object doesn't enter into the category. In the options of responses there was the possibility of partial and complete discrepancy between the word that names the category and the image. The total number of completed Google forms is 846 , the total number of the received responses -12690 . The second experiment also took into account the estimates of the respondents from the control group which included 18 historians, architects and restorers. The scaling method was used to process the results: each object received an average score which determined its place in the structure of the category. The central zone of both categories includes objects with a score of 2.75 and higher. By analyzing the perceptual and functional features of the objects of the central zone we have formed a verbal description
\end{abstract}

(C) Zhuykova, Marharyta; Lavrynovych, Liliia; Svidzynska, Olha, 2020.

This is an Open Access article distributed under the terms and conditions of the Creative Commons Attribution 4.0 International Licence (http://creativecommons.org/licenses/by/4.0).

East European Journal of Psycholinguistics, 7(2), 243-256. https://doi.org/10.29038/eejpl.2020.7.2.zhu

${ }^{1}$ Due to the fact that the Ukrainian word myp cannot be accurately translated into English wall, we use in this article a transliteration of the Ukrainian $m y p$ - MUR. More precisely, the Ukrainian syp corresponds to the German Mauer. 
of the prototypes of the categories PARKAN and MUR. During the processing of experimental data there were found the differences in the principles of formation of the central zones of categories. This is related to the role of these objects in the modern anthropogenic landscape. The assignment of a certain artifact to the category PARKAN is influenced by two factors: perceptual features and function that a person derives from external features. When categorizing an object as a typical MUR not only perceptual features and function are important, but also information that goes beyond current knowledge about the world, namely knowledge about the status and functions of reality in the past.

Keywords: psycholinguistic experiment, categorization, basic level, central zone, prototype.

\section{Жуйкова Маргарита, Лавринович Лілія, Свідзинсыка Ольга. Структура категорій базового рівня у свідомості українців за результатами психолінгвістичних експериментів: Паркан та Мур.}

Анотація. Мета дослідження - експериментальне виявлення структури (передусім центральної зони) двох категорій базового рівня у свідомості носіїв української мови: ПАРКАН та МУР. Для цього було розроблено і проведено два психолінгвістичні експерименти: в першому респондентам пропонувалось визначити приналежність об'єкта на фото до категорії ПАРКАН, в другому - до категорії МУР. Для кожного експерименту було вибрано по 75 зображень об'єктів 3 подібними функціями та перцептивними ознаками. Респонденти мали вибрати під зображенням цілі числа 1-2-3; оцінка 3 маркує входження об’єкта до категорії, оцінка 1 - невходження до неї. У варіантах відповідей була запрограмована можливість часткової та повної невідповідності між словом, яке називає категорію, та зображенням. Загальна кількість заповнених гугл-форм становить 846, загальна кількість отриманих відповідей - 12690. В другому експерименті враховувались також оцінки контрольної групи респондентів, куди увійшло 18 істориків, архітекторів, реставраторів. Для опрацювання результатів використано метод шкалування: кожен об'єкт отримав середню оцінку, на основі якої визначалось його місце у структурі категорії. До центральної зони обох категорій увійшли об’єкти 3 оцінкою 2,75 та вище. Шляхом аналізу перцептивних та функціональних ознак об’єктів центральної зони ми сформували вербальний опис прототипів категорій ПАРКАН та МУР. При опрацюванні експериментальних даних було виявлено відмінності у принципах формування центральних зон категорій, що пов'язані з роллю цих об’єктів у сучасному антропогенному ландшафті. На віднесення певного артефакту до категорії ПАРКАН впливають два чинники: перцептивні ознаки та призначення, яке людина виводить із зовнішніх ознак завдяки своїм фоновим знанням. При категоризації об'єкта як типового МУРА виявляються важливими не лише перцептивні ознаки і функція, а й така інформація, що виходить за межі поточних знань про світ, а саме знання про статус і функції реалії у минулому. Вважається, що інформація про культурноісторичну роль реалії посідає важливе місце у структурі відповідного концепту, однак наше дослідження показало, що такі знання можуть впливати на вміст та будову не лише концептів, а й категорій свідомості.

Ключові слова: психолінгвістичний експеримент, категоризація, базовий рівень, центральна зона, прототип.

\section{Introduction}

Categorization is the selection of discrete categories from the continuum of perceptual information, its verbal design, as well as the procedure for acquiring new objects to the singular explicit category, underlies the processes of cognition and is an important means of human orientation in the world.

Rosch first described the cognitive role of categories of consciousness. The paper (Rosch and Mervis, 1975) emphasizes the special role of basic level categories in cognition of the world, and also contrasts these categories with superordinate and subordinate categories. The defining role of basic level categories, as suggested by E. Rosch and C. Mervis, is related to their informativeness, optimal for human consciousness. The fact is that the categories at the superordinate level are too broad, covering too many objects, so the names of such categories (eg, FRUIT, VEHICLE, 
TOOL, ANIMAL) cannot provide speakers with the information they need to understand the situation or certain operations with realias.

On the other hand, subordinate categories are very narrow, cover much fewer objects, and the set of distinguishing features of each object grows; therefore, the amount of information associated with the corresponding word, the name of the subordinate category, is excessive for the average speaker (for example, the basic category BOAT includes subordinate categories DUGOUT BOAT, BARKAS, WELBOT, BAIDARKA, YAL, CANOE). Excessive amount of information, as noted by E. Rosch, is contrary to the principle of cognitive economy. Instead, basic level categories provide optimization of the amount of information in communication: "That basic objects are categories at the level of abstraction that maximizes cue validity and maximizes category resemblance is another way of asserting that basic objects are the categories that best mirror the correlational structure of the environment" (Rosch, 1978, p. 31).

Active experimental researches, which began in the 1970s by psychologists, were aimed at identifying the properties of categories of different levels in the minds of people. Thus, in profound experiments which were done by American psychologists Murphy and Smith, it was shown that the time it takes for people to classify certain objects is less than that required to recognize subordinate and superordinate level objects. (Murphy \& Smith, 1982). For the purity of the experiment, the researchers modeled images of 14 tools representing the categories of all three levels, and also applied short fictional names to them.

A detailed review of theoretical and experimental research, basic principles, various hypotheses, their critique of basic level categories, as well as subordinate and superordinate categories, is found in the work of Hajibayova (Hajibayova, 2013). This review covers a significant part of the scientific works of philosophers, psychologists and linguists (References contains 71 references, which include almost all major research in this area). According to Hajibayova, at the present stage there is a need to study the categories of the basic level at the interdisciplinary level, which will, in particular, optimally organize information search systems focused on user needs. "Cross-disciplinary studies of basic-level categories may not only help to better understand individuals categorization patterns, but also contribute to the development of systems that would provide more 'organic' juxtaposition of controlled or 'artificial' and user-generated vocabularies. As a result, it may improve representation, organization, 'findability' and effective use of the knowledge" (Hajibayova, 2013, p. $685)$.

Natural cognitive categories, as shown by numerous experiments, are organized on the principle of "center - periphery"; in the center of the category of the basic level is one or more prototype objects, which, according to native speakers, can better than others represent the whole category (Rosch, 1975). The pioneering work in linguistic research, where not only images but also lexical items were used to identify the content of basic level categories, is the work of the American linguist Labov (Labov, 1983). By interviewing respondents, he found out the conditions under which native speakers use lexical items from the group "dishes" such as cup, glass, mug, bowl, pitcher, vase. Labov showed the respondents schematic images of different types of 
utensils, which had certain common features, and asked to name these objects. By the method of mathematical calculations, Labov built a probabilistic model that allows to predict which English word can be applied to a particular subject with certain parameters. From the point of view of cognitology, W. Labov's experiments are aimed at substantiating the indeterminate limits of natural categories, the presence of borderline zones between them, as well as the identification of prototypes of categories CUP, MUG, BOWL, VASE, GLASS and others. It was W. Labov who had the idea to ask the respondents the question: "Would you call this object the word X?", Which implies the answer "yes" or "no".

It should be noted that in Ukrainian psycholinguistics and cognitology there are no studies aimed at studying the basic level categories. Modern experimental studies in these areas mostly deal with such area of mental lexicon organization as associative connections between individual concepts (see the works of Ukrainian scientists Martinek, Karpenko, Horoshko, Nedashkivska, Denysevych); much less often in the sphere of interests of Ukrainian researchers is the structure of categories of superordinate level, look at Khadzhioglova's work on the organization of the category MUSICAL INSTRUMENTS in different linguistic cultures. Our study of two categories of the basic level fills the gap that exists in cognitive studies aimed at analyzing the mental space of Ukrainian speakers.

The relevance of the proposed work is determined by the importance of experimental examination of various categories of consciousness, in particular those that affect the spatial orientation and daily activities of people.

\section{Methods}

\subsection{Procedure. The first experiment is the PARKAN category}

The purpose of our article is, first, to describe the methodology and procedure of two psycholinguistic experiments, as well as to discuss their results. Secondly, we present for scientific discussion our conclusions about the features of the prototype objects of the basic level categories PARKAN and MUR in the minds of Ukrainian speakers. The following methods were used to achieve the goal such as a survey of respondents, during which they responded not to verbal but to visual stimuli, as well as a similar survey of respondents in the control group; method of scaling the results of the survey using two methods (calculating the arithmetic mean; determining the ratio of answers "yes" / "no").

The first psycholinguistic experiment (hereinafter PE-1) was organized as follows. In the process of preparation, 75 different photographs (authors of all photos are Zhuykova and Svidzynska) were selected, which depict various functional objects typical of modern urban and suburban space.

These included actually fences and other means to limit the territory or object (guard rails, curbs, stretched chains, wires or tapes, stone fences around the fountains, metal fences around the graves, railings on the stairs, balustrades on the terraces). All photos were divided between 5 versions and placed in Google forms. Each option includes different photos so that there are both central and peripheral objects that fall into the category of PARKAN as well as objects that limit something, but mostly are not understood as fences. 
The survey was conducted in May 2020. Before the experiment began, potential participants received the following information: "Each photo has an object that separates or encloses part of the space. You need to think about the answer to the question and choose one of the answers based on your own ideas about the objects you know". Respondents were required to indicate their age and name in the form (without a last name, which ensured the anonymity of the survey) and give the image their rating by selecting it from the drop-down scale (1-2-3). Questions and answers to it are formulated in PE-1 as follows: "To what extent does the image in the photo correspond to your ideas about the fence? 1 - No, it's not a fence, 2 - Not quite like that, but maybe, 3 - Yes, it's a fence". Thus, respondents were asked to establish a correspondence between the image and the name of the category expressed in words; it is important that the respondents had to respond not to the semantics of a given word, but to its scope of reference, which was modeled in the photo. In the answer options under the photo, the possibility of partial and complete discrepancy between the word and the image was programmed.

To see the details of the content of all versions of Google forms PE-1: https://cutt.ly/ZsSALTQ; https://cutt.ly/QsSSqVz; https://cutt.ly/wsSGOqN; https://cutt.ly/8s1RV3c; https://cutt.ly/WsSHtI7.

The participants of the experiment were native speakers of the Ukrainian language of both sexes, mostly residents of Volyn and Lviv regions, the average age of respondents is 26.3 years. The total number of completed forms is 460 ; the total number of received answers is 6900 . The exact data on the answers to each of the 75 images is under the link: https://cutt.ly/hsJ87hM (p. PE-1). One photo has an average of 92 answers, which allows us to consider the results representative.

\subsection{The second experiment is the MUR category}

The second experiment (hereinafter PE-2) was built similarly to the first and reproduced its form and content. Google forms also included 75 photos (the authors of all photos, except for one archive were M. Zhujkova and O. Svidzynska), which we divided between the five versions of the questionnaire on the same principle as in PE1. The proposed images show various objects created by man from stone or its analogues; their appearance and purpose are different (you can find the restrictive, defensive, decorative, reinforcing functions). The question to be answered by the respondents was formulated similarly to the question PE-1: "To what extent does the image in the photo correspond to your ideas about the wall? 1 - No, it's not a wall, 2 Not quite like that, but maybe, 3 - Yes, it's a wall".

To see the details of the content of all versions of Google forms PE-2: https://cutt.ly/tsSHZch; https://cutt.ly/DsSHYal; https://cutt.ly/QsSH9Sx; https://cutt.ly/CsSJrWn; https://cutt.ly/2sSJdAU.

The experiment was conducted in July 2020. We changed the target group of respondents: adults of both sexes took part in the survey, mostly with higher education, some of them are scientists. All respondents are native speakers of the Ukrainian language; the average age is 41.7 years. A control group of eighteen historians, architects and restorers was formed among the persons who filled out the forms. As the professional opinion of experts is of special interest to us, we analyzed 
their answers separately; expert assessments are included in the overall calculation of results.

The geography of PE-2 participants was expanded, i.e., the forms were sent to residents of Volyn and L'viv regions, Rivne, Kyiv, Kamianets-Podilskyi, IvanoFrankivsk, Uzhhorod, and a small number to residents of central and eastern parts of Ukraine. 386 completed forms were received; the total number of answers is 5790 . All indicators for answers to each of the 75 images in PE-2 are under the link: https://cutt.ly/hsJ87hM (p. PE-2). The average number of answers per photo is 77.2.

\section{Elaboration of PE-1 and PE-2 results and their discussion}

The results were processed in two ways: first, a general descending scale was constructed, which gives the average score for each photo; secondly, for each image the number of answers "yes" and "no" in percent was taken into account. Estimates of images in PE-1 are in the range from 1.06 (photo 73) to 2.91 (photos 3 and 59); statistical error in evaluating the results we did not take into account. The average scores are entered in the general table (https://cutt.ly/PsSP3QH, p. 1-2).

The scaling of the results for the structure of the PARKAN category showed that the decline in grades occurs smoothly, without jumps and gaps (the average step between adjacent positions is 0.03 points). Because of this, we had to conditionally separate the central zone, in which we included objects with scores of 2.75 and higher. Table 1 presents estimates of eleven objects of the central zone, as well as their brief description:

Table 1

Objects of the central zone of the PARKAN category

\begin{tabular}{|c|c|c|c|}
\hline $\begin{array}{l}\text { Photo } \\
\text { number }\end{array}$ & $\begin{array}{c}\text { Average } \\
\text { rating on a } \\
\text { scale of } 1- \\
3\end{array}$ & $\begin{array}{l}\text { Percentage } \\
\text { of answers } \\
\text { "yes" / "no" }\end{array}$ & Brief characteristic of the object \\
\hline 59 & 2.91 & $93.3 / 2.2$ & $\begin{array}{l}\text { A wooden fence which is made of individual } \\
\text { vertical columns that fit snugly together; } \\
\text { limits the territory of the playground }\end{array}$ \\
\hline 3 & 2.91 & $91.7 / 1.0$ & $\begin{array}{l}\text { Wooden construction fence (temporary) } \\
\text { which is assembled from individual boards }\end{array}$ \\
\hline 51 & 2.84 & $87.6 / 3.4$ & $\begin{array}{l}\text { Modern city fence on a stone foundation, the } \\
\text { top is made of wrought iron details; encloses } \\
\text { a private house }\end{array}$ \\
\hline 64 & 2.80 & $81.9 / 2.1$ & $\begin{array}{l}\text { Fence of individual metal elements, placed } \\
\text { vertically, without a foundation; fences off } \\
\text { the parking lot }\end{array}$ \\
\hline 15 & 2.79 & $83.3 / 4.2$ & $\begin{array}{l}\text { Mesh fence on a stone foundation, mesh is } \\
\text { built into the pillars; fences off a private } \\
\text { estate in the city }\end{array}$ \\
\hline 5 & 2.77 & $81.3 / 4.2$ & $\begin{array}{l}\text { Fence in the form of a metal mesh on a } \\
\text { concrete foundation, encloses a private } \\
\text { house in the city }\end{array}$ \\
\hline
\end{tabular}




\begin{tabular}{cccl}
\hline 7 & 2.77 & $79.2 / 2.1$ & $\begin{array}{l}\text { Fence in the form of low sections of metal } \\
\text { mesh around a private house in the village } \\
\text { A low fence of individual wooden fences } \\
\text { around a small front garden } \\
70\end{array}$ \\
28.77 & $86.0 / 47$ & $81.9 / 5.3$ & $\begin{array}{l}\text { Mesh fence, in which the mesh frame is } \\
\text { attached to metal poles; fences off the } \\
\text { kindergarten }\end{array}$ \\
43 & 2.76 & $81.5 / 5.6$ & $\begin{array}{l}\text { Modern city fence on a stone foundation, the } \\
\text { top of which is made of flat steel pin placed } \\
\text { vertically } \\
\text { Sectional metal fence around the office area, } \\
\text { low, discontinuous }\end{array}$ \\
\hline
\end{tabular}

The results of PE-2 were similarly processed. Estimates of PE-2 objects range from 1.09 (photo 43) to 2.99 (photo 62); statistical error in evaluating the results we did not take into account. The scale of general assessments obtained in PE-2 has only one quantitative gap: between adjacent positions 23 (2.75 points) and 19 (2.59 points) there is a difference of 0.16 points, which allows us to distinguish the central zone of the MUR category and include nine photos. Estimates located on the overall scale then decline very smoothly, as in PE-1, which does not give grounds to reliably distinguish areas of near and far periphery. Information on the objects of the central zone, including their attribution, is given in Table 2.

Table 2

Objects of the central zone of the MUR category

\begin{tabular}{|c|c|c|c|}
\hline $\begin{array}{l}\text { Photo } \\
\text { number }\end{array}$ & $\begin{array}{c}\text { Average } \\
\text { rating on a } \\
\text { scale of } 1- \\
3 \\
\end{array}$ & $\begin{array}{l}\text { Percentage } \\
\text { of answers } \\
\text { "yes" / "no" }\end{array}$ & Short attribution of the object \\
\hline 62 & 2.99 & $98.7 / 1.3$ & $\begin{array}{l}\text { Authentic city wall in Przemyśl, a restored } \\
\text { fragment on the Basztowa } \\
\text { Street. Approximate construction time is XVI } \\
\text { - first half of the XVII century. Another } \\
\text { fragment of the same wall is in the photo } 22\end{array}$ \\
\hline 66 & 2.92 & $94.9 / 2.5$ & $\begin{array}{l}\text { Authentic wall around the territory of the } \\
\text { former Bernardine monastery in L'viv. } \\
\text { Approximate construction time is the } \\
\text { beginning of XVII century, view from the } \\
\text { Mytna Square }\end{array}$ \\
\hline 2 & 2.89 & $92.8 / 3.6$ & $\begin{array}{l}\text { The walls of the fortress in Kamianets- } \\
\text { Podilskyi, modern look after reconstruction }\end{array}$ \\
\hline 11 & 2.88 & $90.4 / 2.4$ & $\begin{array}{l}\text { Former defensive, now retaining wall in the } \\
\text { Old Town of Kamianets-Podilskyi on the } \\
\text { terraces between Ruska and Hospitalna }\end{array}$ \\
\hline
\end{tabular}




\begin{tabular}{|c|c|c|c|}
\hline & & & $\begin{array}{l}\text { Streets. Approximate time of construction: the } \\
\text { first third of the XVIII century }\end{array}$ \\
\hline 35 & 2.88 & $90.5 / 2.7$ & $\begin{array}{l}\text { Archive photo of the remains of the Eastern } \\
\text { defensive wall of Chufut-Kale (Crimea). } \\
\text { Approximate time of construction is the end } \\
\text { of the XIV - the middle of the XV century }\end{array}$ \\
\hline 53 & 2.85 & $89.3 / 4.0$ & $\begin{array}{l}\text { An authentic wall around the former } \\
\text { Franciscans-Observantists monastery in L'viv. } \\
\text { Approximate time of construction is the } \\
\text { middle of the XVII century, view from the } \\
\text { Zamkova Street }\end{array}$ \\
\hline 31 & 2,82 & $86.5 / 4.1$ & $\begin{array}{l}\text { Authentic wall in the eastern part of the Old } \\
\text { Town of Kamianets-Podilskyi on } \\
\text { Dominikanska Street from Pyatnytska Street }\end{array}$ \\
\hline 22 & 2,81 & $88.0 / 6.7$ & $\begin{array}{l}\text { City wall in Przemyśl, view from Basztowa } \\
\text { Street. Approximate time of construction is } \\
\text { XVI - first half of the XVII century. Another } \\
\text { fragment of the same wall is in the photo } 62\end{array}$ \\
\hline 23 & 2,75 & $78.7 / 4.0$ & $\begin{array}{l}\text { Authentic wall around the territory of the } \\
\text { Basilian Monastery in Buchach, Ternopil } \\
\text { region. Approximate time of construction is } \\
\text { the middle of the XVIII century }\end{array}$ \\
\hline
\end{tabular}

The results for the central zone of the MUR category show that the respondents identify with the walls primarily ancient fortifications that performed a defensive function. This function determines, first, the material from which the walls are built: it is either natural stones or fired bricks; individual elements of the walls are combined with a reinforcing solution. Secondly, the defensive function determines the size (height, length and thickness) of the walls.

It should be noted that the lower marks were given to those old walls, which, unlike the objects of the central zone, do not see the masonry of stone or brick, because they are now plastered and whitewashed. Thus, photos 20 and 50 show high walls that separated the territory of the former Benedictine monastery in L'viv (photo from the Memorial Heroyiv Nebesnoyi Sotni near Krivonos Street) (Melnyk, 2010, p. 16). These objects received a score of 2.16 (wall with an open fragment of masonry) and 2.41 (masonry completely covered with plaster). Another example: the territory of the church of St. Lazar in L'viv has an authentic, wellpreserved wall of the XVII century, which stretches along the Kopernyka Street. The wall is covered with plaster now, but its stone foundations can be seen below. We used two photos of this wall (71 and 37) from the same angle and got rather low scores of 2.35 and 2.27. Photo 51 shows the Cathedral of St. Yura in L'viv and the wall in front of it, which is now plastered and whitewashed. This object, despite its considerable height, received a score of 2.24. 
Respondents did not interpret the objects of the new construction, in particular deaf fences in the form of solid stone masonry above human height (for example, photos $28,48,49,57,59,70,72$ ); their estimates range from 1.57 to 1.88 . However, the modern stylization of the fence "à la the wall", presented in photo 46, has an unexpectedly high score of 2.12, which is not surprising, because a close score (2.16) was given to the image of the authentic walls of the Benedictine monastery.

Let's turn to the estimates given by the participants of the experiment, selected in the control group. In total, they filled out 67 Google forms, a total of 1,005 responses; each photo has about 13.4 ratings. The full scale of assessments made by experts can be viewed here: https://cutt.ly/PsSP3QH, p. 3-4. We present comparative results for the central zone in Table 3.

Table 3

Comparative assessments of the objects of the central zone of the MUR category in the general survey and in the group of experts

\begin{tabular}{ccc}
\hline Photo number & All respondents & Experts \\
\hline 62 & 2.99 & 3 \\
66 & 2.92 & 3 \\
2 & 2.89 & 3 \\
11 & 2.88 & 2.92 \\
35 & 2.88 & 2.86 \\
53 & 2.85 & 2.69 \\
22 & 2.81 & 2.86 \\
31 & 2.82 & 2.79 \\
23 & 2.75 & 2.57 \\
19 & 2.59 & 2.71 \\
\hline
\end{tabular}

The central area of the MUR category, presented in the minds of experts, is generally not very different from the one built on the basis of general estimates, but contains two objects less. Specialists dropped objects 23 and 53 from the central zone. In addition, in the control group, photo 19 is closer to the center of the category than in the overall assessment. This photo shows the wall around the Franciscans-Observantists monastery; the same wall is presented in the photo 53 . Expert estimates for this wall are almost the same: 2.69 and 2.71, and the overall estimates have a significant gap of 0.26 (one image falls in the central area, and the other does not). Thus, in total, the experiment identified eight different objects of the central zone of the MUR category.

\section{The problem of selecting the attributes that are inherent in the prototypes of the categories PARKAN and MUR}

After processing all the results of PE-1, we gave access to them to students of philology at Lesya Ukrainka Volyn National University, who also participated in the survey, and asked to describe in general the objects of the central zone. The 
purpose of the task for students was to verbalize the features of the prototype fences with reliance on the own experience of the participant of the experiment, and on the generalized survey data. Here are some answers:

"Prototype fence is a high wooden or metal, solid or non-continuous object that separates one part of the territory from another"; "the prototype fence has a height that is close to human height; $3-4 \mathrm{~cm}$ thick; made of wood or metal mesh and welded panel; performs the main function of fencing a person's place of residence"; "prototype fence is up to about 2 meters; the material must be dense, ie the fence must be a structure that creates the impression of "impassability"; the fence must be strong"; "height is about 1 meter; prototype fence is high, securely encloses the territory", "fence is a rectangular structure without too large holes and other elements that violate its integrity (e.g., wicket), with a height of 1 to 2.5 meters, located on the ground and which separates a certain part of the territory from another; in good enough condition to perform this function"; "the height of the fences should not be lower than approximately $40 \mathrm{~cm}$; the fence must be made of solid materials; the fence must separate one territory from another"; "the prototype fence must be made of metal materials, have a rectangular shape and a height of $1.2 \mathrm{~m}$ to $2 \mathrm{~m}$, enclose or fence off of a certain area or a certain object. It must be intact and form a clear line".

It is noticeable that the signs of fences of the central zone allocated by students are defined by properties of concrete referents and represent considerable variety both external signs, and purpose of fences. In general, we can assume that the problem of invariant characteristics has not been solved; the signs given by students are sometimes contradictory. Thus, defining the main function of fences as «fencing off a person's place of residence», the student does not pay attention to the survey data, in which of the 11 fences of the central zone only five enclose housing, and the remaining six restrict non-residential facilities: playground, construction area, kindergarten, parking lot, front garden, etc. A similar situation is observed with the requirements for the material, size, and density of the prototype fence.

The reason for these difficulties lies primarily in the cognitive complexity of distinguishing features that are part of a holistic gestalt, which is stored in the memory of speakers and serves as a sample in the categorization of real objects of human experience. Discussing the results of Labov's experiment and describing the prototype of the CUP category, Taylor notes: "Thus, the prototypical cup (in Western societies) has a handle, it is made of porcelain, it comes with a saucer; it has a certain overall shape and a typical size; cups are used for drinking hot tea or coffee, and you usually buy them in sets of six" (Taylor, 1995, p. 42). The researcher further remarks: "None of these attributes is essential for membership in the category" (Taylor, 1995, p. 42). Discussing with Labov, Wierzbicka in her work in 1985 offered her approach to the description of categories of household items. In her opinion, it is important to distinguish those features of the category that are not constant and may vary from those that are necessary (non-negative). Necessary attributes for the CUP category Wierzbicka considers, first, the function, i.e., the cup is made to drink hot drinks from it; secondly, the size tied to the 
method of use, i.e., the size of the cup should be such that a person can easily lift it to his mouth, holding it with one hand. Other features, such as the presence of an ear and a saucer, are variable and are not necessary, although, as the author emphasizes, the "ideal" cup must have an ear (handle) and a saucer (Wierzbicka, 1985, p. 59).

A similar situation, in our opinion, occurs when identifying signs of prototype fences: you should look for the set of integral characteristics of the category, which are best manifested in the prototype objects. By generalizing the perceptual features of the objects of the central zone, we form the following description of the prototype PARKAN:

height is determined by human height; the length is sufficient to limit a certain area and is determined by its size; the fence has no gaps (except for a specially built-in gate); the left and right edges are not open: they are either locked to each other or connected to another structure or obstacle; the level of the surface on which the fence passes is approximately the same on both sides: first, this level does not have a sharp difference in height, and secondly, there is soil on both sides of the fence.

The last characteristic is not obvious, but it allows you to exclude from the category of PARKAN those objects that may have all the above features and do not receive the name of the fence: fences on bridges, balustrades on the edge of the terrace, guard rails on the road leading to mountain slope, etc. See photo 18 (guard rails) with a score of 1.30 , photo 65 (fence on the tram bridge) with a score of 1.60 , photo 47 (railings on the stairs) with a score of 1.19. It is important that the fence is located perpendicular to the ground (otherwise, its stability decreases). Such features of the fence as integrity, material, shape, thickness are variable; they depend on the available opportunities, aesthetic guidelines, specific purpose, traditions, and time of construction etc.

It should be noted that in the categorization of a particular phenomenon of reality, including artifacts, a person primarily perceives perceptual features. Speakers associate the functions or purpose of an artifact with its external features or deduce them by implication. Obviously, the main function of the fence is to create an obstacle to the movement of man (animal), the secondary is to highlight the boundaries of a certain area, demarcation of its parts (marking the boundaries of property, danger zone).

Weakening of prototype features in the PARKAN category is observed in transitions from those realities that serve as real obstacles to movement, to peripheral objects of the category that perform a symbolic function, i.e., symbolically mark the prohibition of passage or vehicular passage or mark someone's property (look at the photo $62-$ тин (tyn) in the garden). In general, as we expected, those objects that received a score below 2.00 in PE-1, go beyond the category of PARKAN, although they perform the function of restricting movement.

The prototype of the MUR category has a different set of external features:

it is a large vertical object (this dimension is much larger than a person's height); its material is stone and / or brick; the length of the wall is sufficient to demarcate a large area, and a person can not always cover the entire length of the view from one point; the left and right edges of the wall are not open; the masonry 
has a third essential dimension. i.e., width; the masonry has no gaps, except for structures specially designed for passage or vehicular passage (wickets, gates).

Dimensions and material are dictated by the main historical purpose of the walls such as to serve as a means of defense during hostilities, to protect property and people inside, from the aggressive actions of those who seek to seize them. According to PE-2 data, the central zone of the MUR category includes those objects that have lost their defensive function long time ago, but were built just for it. The prototype objects of the MUR category included the former defensive wall about $10 \mathrm{~m}$ high in Kamianets-Podilskyi, which has already lost its function in the XIX century and is now considered a supporter (Serbina, 2012, pp. 139-140); it is the appearance of reality that allowed respondents to correlate it with the walls.

When the assessment decreases on the general scale, a gradual loss of prototype features of the walls can be observed. As we have already mentioned, those walls that are plastered and whitewashed on the outside received a lower grade. The lower height of the wall than a certain imaginary standard also resulted in a lower estimate. For example, photo 29 shows the stone wall of the Turkish bridge in Kamianets-Podilskyi, the height of the wall is approximately equal to a person's height; this photo has an overall rating of 2.33 (experts gave a slightly higher rating of 2.36). The distance from the prototype is experimentally recorded in those objects that performed a defensive function in the past, but are already severely damaged and not reproduced in its original form. In our materials, these are, in particular, the remains of city fortifications in the center of L'viv about 1 meter high (photo №60), which were discovered during excavations in the late 1970s (Bilushchak, 2012, p. 72). The score of this object on the general scale is 1.72 , and in the sample of specialists the score is significantly higher: 2.08 . It is noticeable that the rank of the object is reduced by those signs that indicate the absence of a basic defensive function; for example, photo 6 shows an authentic, relatively low wall from Kamianets-Podilskyi: on the general scale it has a score of 2.24 (the control group gives a higher score is 2.38), and the lack of unanimity in the reactions of respondents is clearly visible: $47,0 \%$ answered "yes", $22.9 \%$ is "no", the remaining $30.1 \%$ is "not quite similar, but it can be". Photo №40 shows an object with decorative elements (a brick wall around the church of St. Clement in L'viv, built in the XX century); this facility has an overall score of 2.26 and a specialist score of only 2.07. Photo №1 shows a high (up to 4 meters) wall near the existing prison in Lutsk, with barbed wire stretched over its upper part. This wall received a total score of 2.34 from the respondents (control group is 2.46). Thus, the fewer external features of a historic defensive object a wall has, the farther from the center its place in the structure of the category.

\section{Conclusions}

The results of experiments show that in the minds of Ukrainian speakers there are two adjacent categories of the basic level PARKAN and MUR, which have a typical structure for natural categories and are part of a common category of superordinate level (FENCE). In both categories, respondents distinguish well 
between the central and peripheral zones; respondents can also correctly assess those objects that go beyond both of these categories. When evaluating images, the participants of the experiments first pay attention to the appearance of reality, while adequately taking into account its purpose. Objects that fill the central zone of the MUR and PARKAN categories have different historical depths: the prototype wall is an ancient element of the cultural anthropogenic landscape, created several centuries ago (and its former defensive function in modern conditions does not matter), and the prototype fence is subject of relatively recent construction with a clear restrictive function. The center of the MUR category is formed almost identically both in the general calculation of answers and in the answers of specialists. This means that Ukrainian speakers with a fairly high level of background knowledge now have a close idea of the 'ideal' object called $a$ wall. By analyzing the external features of the objects of the central zone of both categories, we were able to identify the characteristics inherent in the prototype fences and walls.

Thus, our experiments showed that the assignment of a particular artifact to a natural category is influenced by the following factors: external features (they are perceived perceptually, sensory organs), functional purpose (it is derived from external features due to background knowledge of the world), and in some cases, a cultural-historical role based not on current knowledge of realities but on information about the status and functions of reality in the past. This is special knowledge that forms the cultural identity of the nation and ensures the longevity of national and cultural traditions. There is a widespread view among linguists that this kind of information is contained in conceptual structures, but our experimental study has shown that it can also affect the content and structure of mental categories.

\section{References}

Білущак T. Оборонні споруди Львова XIV-XVIII ст. Історичні дослідження і збережені пам’ятки. Вісник Національного університету “Львівська політехніка”. 2012. №724. C. 68-73. Retrieved from: http://ena.lp.edu.ua:8080/handle/ntb/14013

Лабов У. Структура денотативных значений / пер. с англ. Н.В. Перцова. Новое 6 зарубежной лингвистике. Вып. 14. М.: Прогресс, 1983. С. 133-176.

Мельник І. Довкола Високого замку шляхами й вулииями Жовківського передмістя та північних околиць міста Львова. Львів: Апріорі, 2010.

Сербіна Г. Оборонний комплекс Руської брами у м. Кам'янець-Подільський. Проблеми дослідження, збереження та реставраџії історичних фортифікацій: Матеріали міжнародної конферениії молодих науковців, Львів, Тустань, 2-4 червня 2011 року. Львів: Вид-во Львівської політехніки, 2012. С. 131-144.

Hajibayova, L. (2013). Basic-level categories: A review. Journal of Information Science, 39(5), 676-687. https://doi.org/10.1177/0165551513481443

Labov, W. (1983). Struktura denotativnykh znachenii [The Structure of denotative value]. In New in foreign linguistics, Ser. 14. (pp. 133-176). Moscow: Progress.

Murphy, G., Smith, E. (1982). Basic-level superiority in picture categorization. Journal of Verbal Learning and Verbal Behavior, 21(1), 1-20. https://doi.org/10.1016/S0022-5371(82)90412$\underline{1}$ 
Rosch, E. (1975). Cognitive representations of semantic categories. Journal of Experimental Psychology, 104, 192-233. https://doi.org/10.1037/0096-3445.104.3.192

Rosch, E., Mervis, C. (1975). Family resemblances: Studies in the internal structure of categories. Cognitive Psychology, 7(4), 573-605. https://doi.org/10.1016/0010-0285(75)90024-9

Rosch, E. (1978). Principles of categorization. In: Rosch, E., Lloyd, B. (eds). Cognition and categorization. (pp. 27-48). Hillsdale, NJ: Lawrence Erlbaum.

Taylor, J. R. (1995). Linguistic Categorization. Prototypes in Linguistic Theory. Second Edition. Oxford University Press, New York, USA

Wierzbicka, A. (1985). Lexicography and Conceptual Analysis. Ann Arbor.

\section{References (translated and transliterated)}

Bilushchak, T. (2012). Oboronni sporudy L'vova XIV-XVIII st. Istorychni doslidzhennya i zberezheni pamyatky [The Defensive Structures of Lviv XIV-XVIII c. Historical Research and Preserved Monuments]. Herald of Lviv Polytechnic National University, 724, 68-73. Retrieved from: http://ena.lp.edu.ua:8080/handle/ntb/14013

Melnyk, I. (2010). Dovkola Vysokoho zamku shlyakhamy y vulytsyamy Zhovkivs'koho peredmistya ta pivnichnykh okolyts' mista Lvova. [Around the High Castle by roads and streets of Zhovkva suburb and northern outskirts of Lviv]. Lviv : Apriori.

Serbina, H. (2012). Oboronnyy kompleks Rus'koyi bramy u m. Kamyanets'-Podil's'kyy. Problemy doslidzhennya, zberezhennya ta restavratsiyi istorychnykh fortyfikatsiy [The Defense complex of Ruthenian Gates in Kamyanets-Podilsky]. In: Current issues in research, conservation and restoration of historical fortifications. Materials of International Conference for Young Researchers. Book of abstracts. L'viv Polytechnics Publishing House. (131-144).

Hajibayova, L. (2013). Basic-level categories: A review. Journal of Information Science, 39 (5), 676-687. https://doi.org/10.1177/0165551513481443

Labov, W. (1983). Struktura denotativnykh znachenii [The Structure of denotative value]. In T. Zevakhina, B. Gorodetskiy, (Eds.). Novoye v Zarubezhnoy Lingvistike, No. 14. (pp. 133176). Moscow: Progress.

Murphy, G., Smith, E. (1982). Basic-level superiority in picture categorization. Journal of Verbal Learning and Verbal Behavior, 21(1), 1-20. https://doi.org/10.1016/S0022-5371(82)904121

Rosch, E. (1975). Cognitive representations of semantic categories. Journal of Experimental Psychology, 104, 192-233. https://doi.org/10.1037/0096-3445.104.3.192

Rosch, E., Mervis, C. (1975). Family resemblances: Studies in the internal structure of categories. Cognitive Psychology, 7(4), 573-605. https://doi.org/10.1016/0010-0285(75)90024-9

Rosch, E. (1978). Principles of categorization. In: Rosch, E., Lloyd, B. (Eds). Cognition and categorization. (pp. 27-48). Hillsdale, NJ: Lawrence Erlbaum.

Taylor, J. R. (1995). Linguistic Categorization. Prototypes in Linguistic Theory. Second Edition. Oxford University Press, New York, USA

Wierzbicka, A. (1985). Lexicography and Conceptual Analysis. Ann Arbor. 